\title{
PERILAKU HARGA DAN INTEGRASI PASAR HORIZONTAL BERAS DI PROPINSI BENGKULU
}

\section{PRICE BEHAVIOR AND HORIZONTAL MARKET INTEGRATION OF RICE IN BENGKULU PROVINCE}

\author{
Cahya Suryana, Putri Suci Asriani, dan Redy Badrudin \\ Jurusan Magister Agribisnis Fakultas Pertanian Universitas Bengkulu \\ cahyasuryana_agb3@yahoo.com
}

\begin{abstract}
Rice is one of the strategic foods in Indonesia. According to Alimoeso (2011), approximately 95\% of the Indonesian people depend on rice, poor families allocate nearly $21.8 \%$ of its expenditure on rice. In addition, of rice consumption estimates is the highest Indonesian in Southeast Asia, namely, $139 \mathrm{~kg} /$ capita / year, of which about $120 \mathrm{~kg}$ consumed directly. That is why price policy is important instrument for improving the wealth of rice farmers as well as rice traders. The purpose of the study was to analyze the price behavior, (2) analyze market integration (3) to analyze market causality, and (4) determine the rice leader market in Bengkulu Province. This study used a method of analysis of price behavior, market integration, unit root test, cointegration test and analysis methods of Engle and Granger causality. The results rice price behavior in Bengkulu do not fluctuate indicating by lower value of show that coefficient variable. There is strong integration market in price formation between Bengkulu, Rejang Lebong, North Bengkulu and South Bengkulu markets. The causality test proved that the prices of the price of North Bengkulu affect the price rice Bengkulu City, Rejang Lebong and South Bengkulu, and none of the three areas that affect the price of rice in North Bengkulu, and the leader market is North Bengkulu.
\end{abstract}

Keywords: price behaviour, horizontal market integration, rice, market leader

\section{PENDAHULUAN}

Beras merupakan salah satu pangan strategis yang sangat penting di Indonesia. Menurut Alimoeso (2011), sekitar 95\% rakyat Indonesia tergantung kepada beras, keluarga miskin menyisihkan hampir $21.8 \%$ dari pengeluaranya untuk beras dan perkiraan konsumsi beras rakyat Indonesia yang tertinggi di Asia Tenggara yaitu $139 \mathrm{~kg} / \mathrm{kapita} /$ tahun, sekitar $120 \mathrm{~kg}$ diantaranya dikonsumsi secara langsung. Senada dengan Alimoeso, Lantarsih (2012) mengungkapkan bahwa beras merupakan makanan pokok utama dan cenderung tunggal di berbagai daerah di Indonesia, dan ketersediaannya tetap menjadi perhatian pemerintah karena menyangkut harkat dan keberlanjutan eksistensi bangsa. 
Berdasarkan data BPS (2013), produksi padi Provinsi Bengkulu sebanyak 622.83 ribu ton Gabah Kering Giling (GKG). Dibandingkan dengan tahun 2012 meningkat sebanyak 40.92 ribu ton (naik 7.03\%). Peningkatan tersebut disebabkan peningkatan luas panen seluas 3.23 ribu hektar (naik 2.24\%)dan produktivitas sebanyak 1.88 kuintal/hektar (naik $4.68 \%$ ). Peningkatan produksi padi berasal dari produksi padi sawah yang meningkat sebanyak 47.32 ribu ton atau naik $8.59 \%$, dan penurunan produksi padi ladang $20.55 \%$. Produksi padi sawah Provinsi Bengkulu tahun 2013 sebanyak 598.11 ribu ton ( 96.03\%) dan padi ladang sebanyak 24.72 ribu ton (3.07\%).

Di kabupaten-kabupaten dengan sumber daya alam yang melimpah seperti yang ada di Propinsi Bengkulu, kecenderungan terhadap kenaikan harga komoditas beras menciptakan peluang maupun tantangan. Untuk merumuskan kebijakan yang efektif dalam rangka memanfaatkan peluang dan menghadapi tantangan tersebut, sangat penting agar pembuat kebijakan (pemerintah kabupaten/kota) memahami sejauh mana lokal (kabupaten) di Bengkulu terintegrasi dengan pasar kabupaten yang lain dan dengan pasar provinsi maupun nasional.

Berdasarkan latar belakang tersebut di atas, maka penelitian ini dilakukan dengan tujuan: (1) menganalisis perilaku harga beras, (2) menganalisis integrasi pasar antar pasar beras, (3) menganalisis kausalitas antar pasar yang terintegrasi, dan (4) menentukan pasar penentu/leader market dari hasil analisis kausalitas di Propinsi Bengulu.

\section{METODE PENELITIAN}

Penelitian ini menggunakan metode deskritif. Data yang digunakan dalam penelitian ini adalah data times series yang berupa data bulanan harga beras di tingkat eceran (konsumen) dari Biro Pusat Statistik Bengkulu yang terdiri dari : (a) Kota Bengkulu dari tahun 2004 - 2013, (b) Rejang Lebong dari tahun 2004 - 2013, (c) Bengkulu Utara dari tahun 2004 -2013 dan (d) Bengkulu Selatan 2004 - 2013. Lokasi penelitian adalah di kabupaten/kota di Provinsi Bengkulu yang ditetapkan secara purposive, yaitu Kota Bengkulu, Kabupaten Rejang Lebong, Bengkulu Utara dan Bengkulu Selatan.

\section{Analisis Perilaku Harga}

Analisis ini menggunakan analisis koefisien variasi harga. Koefisien variasi diperoleh dari standar deviasi suatu variabel dibagi dengan nilai rataratanya (Supriyati, dkk, 1998 dalam Nidausoleha, 2007). Koefisien variasi menggambarkan fluktuasi (simpangan terhadap rata-rata), dimana fluktuasi tersebut menggambarkan resiko yang terjadi. Jika nilai koefisien variasi semakin tinggi maka simpangan terhadap rata-rata semakin tinggi pula, berarti 
akan semakin berfluktuasi. Selanjutnya untuk menarik kesimpulan tentang kondisi harga beras di masing-masing Kabupaten/Kota koefisien variasi tersebut dikelompokkan berdasarkan kriteria di bawah ini:

1. $\mathrm{KV}>66.67=$ "harga sangat berfluktuasi",

2. $33.33 \leq \mathrm{KV} \leq 66.67$ = "harga berfluktuasi",

3. $\mathrm{KV}<33.33=$ "Harga tidak berfluktuasi".

\section{Analisis Integrasi Pasar}

Analisis dilakukan untuk menguji apakah ada integrasi (keterpaduan) antara harga di pasar yang satu dengan pasar yang lainnya. Tingkat integrasi pasar beras dalam penelitian ini diukur antara pasar konsumen satu kota/kabupaten dengan pasar konsumen kabupaten yang lainnya yang ada di Propinsi Bengkulu dengan pendekatan kointegrasi yang dilakukan secara bertahap, yaitu : (1) menguji apakah data times series yang diteliti bersifat stasioner, atau pada orde berapa data yang diteliti bersifat stasioner, (2) menguji apakah dua variabel yang diteliti memiliki orde yang sama, (3) menguji kointegrasi, yang hanya dapat dilakukan jika dua variabel yang diuji adalah stasioner pada orde yang sama.

\section{Uji Akar Unit}

Uji akar unit yang digunakan adalah model Augmented Dicky-Fuller (ADF). Jumlah lag akan ditentukan dengan pendekatan kriteria Akaike, dihitung secara otomatis menggunakan program yang tersedia pada Eviews seri 7. Menurut Asriani (2013), apabila dari uji ini ternyata data belum stasioner maka pengujian dilakukan lagi dengan data turunan kedua. Dengan model yang sama, dengan menggunakan data turunan kedua $\mathrm{Pt}$ dan data turunan pertama untuk Pt-1, selanjutnya dilakukan uji derajat integrasinya: jika $\beta=1$ maka variabel $P$ stasioner pada derajat satu.

\section{Uji Kointegrasi}

Uji"kointegrasi hanya dapat dilakukan jika pasangan data yang akan diuji menunjukkan stasioner pada orde yang sama. Selanjutnya, untuk menguji rangkaian data harga dan rangkaian residu pada persamaan kointegrasi stasioner atautidak digunakan uji t sebagai berikut:

$$
t_{\text {hitung }}=\frac{\beta_{i}}{S e_{\beta_{i}}}
$$

dimana $\beta_{i}$ merupakan parameter yang diestimasi, dan Se $\beta$ i adalah Standard error dari parameter yang diestimasi. Kemudian untuk menguji apakah rangkaian data residu pada persamaan kointegrasi stasioner/tidak, digunakan uji t. 


\section{Analisis Kausalitas}

Analisis kausalitas dilakukan untuk mengetahui pasar pemimpin dan sekaligus menentukan pasar referensi untuk tujuan penjualan atau pembelian beras di propinsi Bengkulu. Model yang dapat digunakan untuk análisis kausalitas ini adalah model yang dikembangkan oleh Granger $(1983,1986)$ dan Engle dan Granger (1987) dalam Asriani (2013) yang didasarkan pada representasi koreksi kesalahan (error correction representation). Analisis kausalitas model Granger standar dilakukan untuk menentukan arah kausalitas harga yang terjadi antar pasar. Oleh karena seluruh data stasioner pada derajat satu, maka analisis model Granger $(1983,1986)$ menggunakan data turunan pertama pada model kausalitas standar.

\section{HASIL DAN PEMBAHASAN}

\section{Analisis Perilaku Harga Beras di Bengkulu}

Harga beras yang terbentuk di pasar Kabupaten/Kota Bengkulu relatif tidak berfluktuasi. Dari hasil analisis perilaku harga dengan pendekatan grafik bulanan beras selama periode 2004-2013, baik di Kota Bengkulu maupun di pasar Kabupaten lainnya menunjukkan pergerakan yang sama. Menurut Nidausoleha (2007), koefisien variasi (KV) menggambarkan fluktuasi (simpangan terhadap rata-rata), dimana fluktuasi tersebut menggambarkan resiko. Resiko yang dimaksud adalah kurangnya kemampuan pasar tersebut dalam menentukan harga jual. Keadaan ini juga menggambarkan bahwa tidak seimbangnya supply-demand beras. Pada tabel berikut disajikan hasil perhitungan koefisien variasi harga beras di Propinsi Bengkulu.

Dari tabel di atas terlihat harga beras Kota Bengkulu mempunyai nilai Koefisien Variasi (KV) yang paling besar yaitu $0.52 \%$. Sementara nilai KV tiga daerah lainnya jauh lebih kecil (hampir sepersepuluh) dari nilai KV Kota Bengkulu yaitu hanya $0.05 \%$. Dengan kata lain fluktuasi harga beras di Kota Bengkulu 10 kali lipat lebih fluktuatif dari fluktuasi harga beras di Bengkulu Utara. Lebih berfluktuasinya harga beras di Kota Bengkulu menunjukan kurang efisienya pasar beras di Kota Bengkulu dibanding daerah lain. Menurut Prastowo, et. al. (2008) harga pasar yang berfluktuasi atau pasar yang tidak efisien dapat disebabkan oleh rantai pemasaran yang terlalu panjang dan atau oleh marjin keuntungan yang terlalu besar yang ditetapkan oleh suatu mata rantai pemasaran.

Tabel 1. Perilaku Harga Beras Di Kabupaten/Kota Bengkulu Dari Tahun 2004 Sampai Tahun 2013

\begin{tabular}{|c|c|c|c|c|c|}
\hline Tahun & Harga & $\begin{array}{c}\text { Kota } \\
\text { Bengkulu }\end{array}$ & $\begin{array}{l}\text { Rejang } \\
\text { Lebong }\end{array}$ & $\begin{array}{c}\text { Bengkulu } \\
\text { Utara }\end{array}$ & $\begin{array}{c}\text { Bengkulu } \\
\text { Selatan }\end{array}$ \\
\hline
\end{tabular}

134 | Cahya Suryana, Putri Suci Asriani, dan Redy Badrudin, Perilaku Harga 


\begin{tabular}{llrrrr}
\hline 2004 & Rerata(Rp) & 2709.91 & 2768.14 & 2632,42 & 2516,81 \\
& KV $(\%)$ & 0.47 & 1.27 & 1.33 & 0.57 \\
2005 & Rerata(Rp) & 3506.91 & 3699.22 & 3588.81 & 3115.31 \\
& KV (\%) & 0.39 & 0.72 & 0.37 & 0.29 \\
2006 & Rerata(Rp) & 4375.10 & 4617.45 & 5609.58 & 3396.67 \\
& KV (\%) & 0.39 & 0.54 & 0.14 & 0.33 \\
2007 & Rerata(Rp) & 5019.58 & 5050.00 & 5604.58 & 4536.50 \\
& KV (\%) & 0.24 & 0.00 & 0.38 & 0.14 \\
2008 & Rerata(Rp) & 5441.67 & 5945.83 & 5452.08 & 4910.42 \\
& KV (\%) & 0.54 & 0.28 & 0.94 & 0.27 \\
2009 & Rerata(Rp) & 5771.25 & 5876.25 & 5552.08 & 5177.92 \\
& KV (\%) & 0.68 & 0.77 & 0.67 & 0.27 \\
\multirow{2}{*}{2010} & Rerata(Rp) & 6655.83 & 7500.83 & 7474.17 & 6257.08 \\
& KV (\%) & 0.19 & 0.62 & 0.27 & 0.24 \\
& Rerata(Rp) & 6941.58 & 7843.92 & 7353.75 & 7452.17 \\
& KV $(\%)$ & 0.28 & 0.22 & 0.31 & 0.14 \\
2012 & Rerata(Rp) & 9365.75 & 8984.42 & 8429.33 & 8439.83 \\
& KV (\%) & 0.50 & 0.37 & 1.33 & 0.32 \\
2013 & Rerata(Rp) & 9131.33 & 9012.75 & 8701.92 & 8007.17 \\
& KV (\%) & 0.70 & 0.28 & 0.14 & 0.44 \\
\hline
\end{tabular}

Sumber : Hasil Analisis Data Sekunder (2014)

Hal lain yang menyebabkan paling berfluktuasinya harga beras di Kota Bengkulu dibanding tiga daerah lainnya adalah banyaknya transaksi jual-beli beras di Kota Bengkulu. Transaksi dan volume perdagangan beras di Kota Bengkulu, hanya untuk mencukupi kebutuhan minimal (menutupi defisisit saja) adalah sebesar 28.864 ton beras/tahun. Jika diumpamakan beras tersebut diangkut oleh truk besar (Fuso) dengan kapasitas angkut 10 ton, maka Kota Bengkulu membutuhkan 2.886 truk Fuso per tahun. Jika tidak ada libur transaksi beras dalam 1 tahun, maka akan ada transaksi sebanyak 8 truk Fuso per hari. Jika transaksi tersebut merata dilakukan di tiga pasar besar yang ada di Kota Bengkulu, yaitu Pasar Panorama, Pasar Minggu dan Pasar Baru Koto, maka akan ada sekitar 3 truk Fuso yang dibongkar dimasing- masing pasar setiap harinya.

Dengan besarnya nilai dan transaksi beras yang terjadi di Kota Bengkulu, menjadikan Kota Bengkulu sebagai pusat distribusi beras di Propinsi Bengkulu dari wilayah surplus kepada wilayah defisit atau ke wilayah yang surplusnya lebih kecil, seperi Rejang Lebong, yang hanya surplus untuk 4 bulan. Besarnya nilai transaksi beras di Kota Bengkulu akan menarik minat pelaku pemasaran/rantai pemasaran beras yang lebih panjang. Sehingga peluang terjadinya fluktuasi harga beras di Kota Bengkulu menjadi lebih besar. Hal ini 
senada dengan pendapat Anindita (2004) yang menjelaskan bahwa fluktuasi harga komoditi pertanian disebabkan oleh tiga alasan, yaitu karena naik turunnya permintaan (fluctuation in demand), naik turunnya penawaran (fluctuation supply), dan eksperimentasi dalam proses penentuan harga. Semakin banyak saluran/lembaga pemasaran terlibat, semakin variatif kondisi keuangan yang dimiliki oleh lembaga tersebut yang akan berdampak pada fluktuasi permintaan dan penawaran, termasuk menahan beras atau melakukan abuse of power untuk keuntungan sesaat.

Hal sebaliknya terjadi di tiga daerah lain yaitu Rejang Lebong, Bengkulu Utara dan Bengkulu Selatan hampir semuanya 10 kali lipat lebih stabil dibandingkan Kota Bengkulu (dilihat dari KV hanya 0.05\% sementara Kota Bengkulu $0.5 \%$ ). Hal ini menunjukan bahwa fluktuasi harga yang lebih kecil menandakan pasar tersebut lebih effisien. Menurut KPPU (2010) pasar yang efisien adalah pasar yang menyampaikan barang (beras) dari produsen (petani) ke konsumen dengan harga semurah-murahnya dan mampu memberikan keuntungan yang adil terhadap semua yang terlibat dalam pemasaran. Terbukti dari tabel diatas bahwa harga rata-rata beras dari Bengkulu Selatan adalah paling murah Rp 5.380,59 dan KV juga yang terkecil yaitu $0.0492 \%$. Diantara empat daerah yang diteliti dalam penelitian ini yaitu Kota Bengkulu. Rejang Lebong, Bengkulu Utara dan Bengkulu Selatan, yang paling stabil harga berasnya dan paling efisien pasar berasnya adalah Bengkulu Selatan.

Meskipun demikian secara umum komoditas harga padi/beras di Propinsi Bengkulu sangat stabil dengan maksimum KV hanya 0.52\% bandingkan dengan komoditi pertanian lainnya, misal cabe merah di Bengkulu yang bisa mencapai 50\% (Sandra et al., 2012). Hal ini dapat dimengerti karena beras merupakan komoditas sosial politik yang menyangkut stabilitas dan keamanan negara, sehingga pemerintah membuat lembaga khusus seperti BULOG dan mebuat lembaga lain untuk menjamin stabilitas seperti LDPM (Lembaga Distribusi Pangan Masyarakat).

\section{Uji Stasioneritas Harga Beras}

Analisis stasioneritas akar unit setiap data harga beras di pasar Kota Bengkulu, Rejang Lebong, Bengkulu Selatan dan Bengkulu Utara menggunakan model analisis Augmented test Dickey-Fuller (ADF). Hasil uji akar unit (ADF test) di ke empat pasar beras di Propinsi Bengkulu dapat dilihat pada Tabel 2. 
Tabel 2. Hasil Uji Akar Unit (ADF test) Data Harga Beras Bulanan 20042013

\begin{tabular}{lccc}
\hline \multirow{1}{*}{ Harga } & \multicolumn{2}{c}{ Uji Akar Unit Tingkat 1st Difference } \\
\cline { 2 - 4 } & Lag & ADF test (t-statistik) \\
\hline Kota Bengkulu & 0 & $-9.466155^{* * *}$ \\
Rejang Lebong & 1 & $-9.134533^{* * *}$ \\
Bengkulu Utara & 0 & $-12.14531^{* * *}$ \\
Bengkulu Selatan & 0 & $-12.14474^{* * *}$ \\
Nilai Kritis & $1 \%$ & -3.486551 \\
MacKinnon & $5 \%$ & -2.886074 \\
\hline
\end{tabular}

Sumber: Hasil Analisis Data Sekunder (2014)

Keterangan : ** Signifikan pada a $1 \%$ ** Signifikan pada a $5 \%$

Hasil estimasi yang diperoleh ditunjukan dalam tabel diatas dapat dilihat nilai t-statistik Kota Bengkulu (-9.466155), Rejang Lebong (-9.134533), Bengkulu Utara (-12.14531) dan Bengkulu Selatan (-12.14474). Terlihat bahwa nilai tstatistik data harga ke empat pasar tersebut lebih besar dari nilai kritis MacKinnon (-3.486551) pada taraf signifikansi (a) $1 \%$ sehingga dapat dinyatakan bahwa $\mathrm{H} 0$ ditolak dan menerima H1. Jadi dapat disimpulkan bahwa data harga beras pada ke empat pasar tersebut stasioner pada taraf kepercayaan $99 \%$. Pengujian stasionaritas data ini penting dilakukan, karena biasanya data time series mengandung akar unit. Akar unit ini dapat menyebabkan regresi yang signifikan secara statistik dan nilai koefisien determinasi yang tinggi, namun hubungan antar variabel didalam model tidak saling berhubungan (Widarjono, 2013).

\section{Uji Kointegrasi}

Uji kointegrasi dilakukan dengan cara meregresi variabel harga antar pasar yang telah stasioner. Selanjutnya diuji apakah residu persamaan regresi tersebut mengandung akar unit atau tidak dengan menggunakan DF Test pada tingkat level. Jika hasil pengujian tidak mengandung akar unit maka residu persamaan tersebut adalah stasioner dan dapat disimpulkan bahwa antar variabel harga yang diregresi tersebut saling berkointegrasi atau berkerterpaduan, Pada hasil uji tersebut terdapat tingkat signifikasi (a) 1\% yang menujukan tingkat keterpaduan yang kuat, (a) 5\% yang menunjukan tingkat keterpaduan sedang, dan (a) 10\% yang menunjukan tingkat keterpaduan yang lemah. 


\section{Integrasi Pasar Spasial}

Integrasi spasial dapat didefinisikan sebagai suatu perubahan harga dalam satu pasar yang direfleksikan ke dalam perubahan harga di pasar yang berbeda secara geografis untuk produk yang sama dan hasil ujinya dapat dilihat pada tabel berikut.

Tabel 3. Hasil Uji Akar Unit (DF Test level I(0)) Residual Kointegrasi antar pasar di Propinsi

\begin{tabular}{lcccc}
\hline & Kota Bengkulu & $\begin{array}{c}\text { Bengkulu Selatan } \\
\text { (manna) }\end{array}$ & $\begin{array}{c}\text { Rejang Lebong } \\
\text { (Curup) }\end{array}$ & $\begin{array}{c}\text { Bengkulu } \\
\text { Utara } \\
\text { (ArgaMakmur) }\end{array}$ \\
\hline Kari & & $-4.802015^{* * *}$ & $-4.472021^{* * *}$ & $-3.211771^{* * *}$ \\
& $(-0.345082)$ & $(-0.303545)$ & $(-0.163495)$ \\
Bengkulu Selatan & $-5.423942^{* * *}$ & & $-5.654592^{* * *}$ & $-3.793562^{* * *}$ \\
(manna) & $(-0.411747)$ & & $(-0.432316)$ & $(-0.221960)$ \\
Rejang Lebong & $-4.417478^{* * *}$ & $-4.979792^{* * *}$ & & $-4.062106^{* * *}$ \\
(Curup) & $(-0.291202)$ & $(-0.354183)$ & & $(-0.250628)$ \\
Bengkulu Utara & $-2.828117^{* * *}$ & $-2.959526^{* * *}$ & $-3.473822^{* * *}$ & \\
(ArgaMakmur) & $(-0.129819)$ & $(-0.146384)$ & $(-0.194247)$ & \\
\hline Nilai Kritis & $1 \%$ & -2.584877 & & \\
MacKinnon & $5 \%$ & -1.943587 & & \\
\hline Sumber: & & & & \\
\hline
\end{tabular}

Sumber: Hasil Analisis Data Sekunder (2014)

Hasil analisis uji kointegrasi di atas menunjukkan bahwa pasar beras Kota Bengkulu terintegrasi sangat kuat dengan pasar beras Rejang Lebong, Bengkulu Utara dan Bengkulu Selatan. Hal ini terlihat dari nilai t-hitung masing-masing kombinasi pasar yang menunjukkan signifikan terhadap nilai kritis MacKinnon pada taraf kepercayaan 99\%. Koefisien regresi pada tabel di atas menunjukkan arah dan seberapa besar pengaruh dari hubungan tersebut terhadap kedua pasar yang terintegrasi. Dari keofisien regresi terlihat bahwa terjadi hubungan negatif dari masing-masing kombinasi pasar beras yang ada di Bengkulu.

\section{Uji Granger Causality}

Uji kausalitas yang digunakan dalam penelitian ini adalah uji Granger Causality. Uji Kausalitas akan dilakukan terhadap pasar beras di Propinsi Bengkulu. Uji kausalitas ini bertujuan untuk mengetahui hubungan sebab akibat antara dua pasar dan hasilnya tertera pada tabel berikut. 
Tabel 4. Hasil analisis Kausalitas (Granger Causality) antar pasar konsumen di Propinsi Bengkulu.

\begin{tabular}{lcccc}
\hline & Kota Bengkulu & $\begin{array}{c}\text { Bengkulu Selatan } \\
\text { (manna) }\end{array}$ & $\begin{array}{c}\text { Rejang Lebong } \\
\text { (Curup) }\end{array}$ & $\begin{array}{c}\text { Bengkulu } \\
\text { Utara } \\
\text { (ArgaMakmur) }\end{array}$ \\
\hline Kota Bengkulu & $1.86237^{\text {ns }}$ & $4.42261^{* * *}$ & $0.60880^{\text {ns }}$ \\
$\begin{array}{l}\text { Bengkulu Selatan } \\
\text { (manna) }\end{array}$ & $12.9972^{* * *}$ & & $7.57261^{* * *}$ & $2.34733^{\text {ns }}$ \\
$\begin{array}{l}\text { Rejang Lebong } \\
\text { (Curup) }\end{array}$ & $3.24991^{*}$ & $2.21262^{\text {ns }}$ & & \\
$\begin{array}{l}\text { Bengkulu Utara } \\
\text { (ArgaMakmur) }\end{array}$ & $6.04777^{* * *}$ & $4.93906^{* * *}$ & $5.59944^{* * *}$ & \\
\hline $\begin{array}{l}\text { Nilai Kritis } \\
\text { MacKinnon }\end{array}$ & $1 \%$ & -6.86 & & \\
\hline
\end{tabular}

Sumber: Hasil Analisis Data Sekunder (2014)

\section{Kausalitas Kota Bengkulu dengan Bengkulu Selatan}

Dari hasil uji Granger Causality berdasarkan uji F, pasar beras Kota Bengkulu dan pasar beras Bengkulu Selatan memiliki hubungan satu arah (F statistik Kota Bengkulu - Manna $=1.86237^{\mathrm{ns}}$ dan F statistik Manna- Kota Bengkulu $=12.9972^{* * *}$ ). Hal ini menunjukan bahwa pasar beras Manna lebih dominan dari pada pasar beras Kota Bengkulu. Artinya perubahan harga beras yang terjadi di Manna dapat diterima dengan baik oleh pasar beras Kota Bengkulu waktu kelambanan selama 2 bulan (dilihat dari nilai lag yaitu 2).
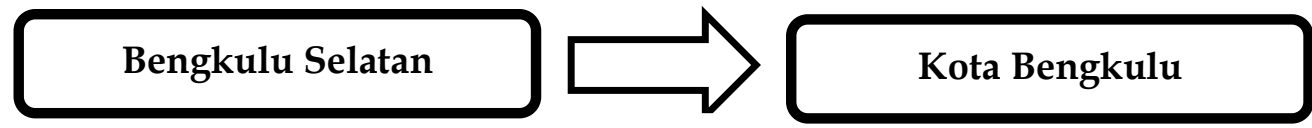

$12,9972^{*}$

\section{Keterangan : $\longrightarrow$ Arah kausalitas}

Sumber : Hasil Analisis Data Sekunder (2014)

\section{Gambar 1.}

\section{Kausalitas Kota Bengkulu dengan Kabupaten Bengkulu Selatan}

Dari gambar tersebut dapat dilihat bahwa pasar beras Bengkulu Selatan lebih dominan dari pada pasar beras Kota Bengkulu dalam penentuan harga. Kondisi ini terjadi karena produksi beras Bengkulu Selatan (Manna) jauh lebih 
besar dari produksi beras Kota Bengkulu. Disamping produksi yang besar, di Bengkulu Selatan juga terjadi surplus beras setiap bulannya, dan besarnya surplus cukup untuk kebutuhan 15 bulan kebutuhan warga Bengkulu Selatan. Besar kecilnya harga beras ikut mengalir bersama perpindahan beras, ditambah biaya pemasaran dan keuntungan pedagang/pengusaha yang melakukan transfer beras dari Bengkulu Selatan ke Kota Bengkulu.

Daya tawar atau arah kausalitas dalam penentuan harga beras Bengkulu Selatan lebih dominan dibanding Kota Bengkulu, karena beras yang cukup banyak, dan adanya pasar potensial lain yaitu Propinsi Lampung. Keunggulan kompetitif lain adalah kekuatan brands yang dimiliki Bengkulu Selatan yaitu beras Kedurang dan beras Seginim. Dilihat dari kasus hubungan antara Bengkulu Selatan dengan Kota Bengkulu, yang terjadi adalah integrasi vertical, dimana Bengkulu Selatan bertindak sebagai produsen/manufaktur/pedagang perantara untuk Kota Bengkulu.

\section{Kausalitas Kota Bengkulu dengan Rejang Lebong}

Berdasarkan nilai F-statisik di atas, terlihat bahwa pasar beras Kota Bengkulu dengan pasar beras Rejang Lebong memiliki hubungan dua arah (Fstatistik Kota Bengkulu- Rejang Lebong $=4.42261^{* * *}$ dan F-statistik Rejang Lebong - Kota Bengkulu= 3.24991*). Hal ini menunjukkan bahwa harga beras Kota Bengkulu akan mempengaruhi harga beras di Rejang Lebong, begitu juga sebaliknya.



\section{Keterangan : $\longrightarrow$ Arah kausalitas}

Sumber : Hasil Analisis Data Sekunder (2014)

\section{Gambar 2.}

\section{Kausalitas Harga Beras Kota Bengkulu dengan Rejang Lebong.}

Dari gambar tersebut dapat dilihat bahwa kausalitas antara Kota Bengkulu dengan Rejang Lebong terjadi dalam dua arah, tetapi pengaruh harga Kota Bengkulu terhadap Rejang Lebong jauh lebih kuat yang disebabkan oleh Kota Bengkulu sebagai kota Transit Beras yang datang dari wilayah surplus beras (lumbung beras) seperti Bengkulu Selatan dan Bengkulu Utara. 
Jarak dari Bengkulu Utara ke Kota Bengkulu lebih dekat $(90 \mathrm{~km})$, dibanding dengan jarak dari Bengkulu Utara ke Rejang Lebong $(160 \mathrm{~km})$. Begitu juga jarak dari lumbung beras Bengkulu Selatan ke Kota Bengkulu $(300 \mathrm{~km})$ lebih dekat dibanding jarak dari Bengkulu Selatan ke Rejang Lebong (370 km). Disamping masalah jarak, kondisi transaksi atau volume perdagangan beras di Kota Bengkulu jauh lebih tinggi dibanding transaksi dan volume perdagangan beras di Kabupaten Rejang Lebong.

\section{Kausalitas Kota Bengkulu dengan Bengkulu Utara}

Berdasarkan nilai F-statisik di atas, terlihat bahwa pasar beras Kota Bengkulu dengan pasar beras Rejang Lebong memiliki hubungan satu arah (Fstatistik Kota Bengkulu- Bengkulu Utara $=0.60880$ ns dan F-statistik Rejang Lebong - Kota Bengkulu= 3.24991 ${ }^{* * *}$ ). Hal ini menunjukkan bahwa harga beras Bengkulu Utara akan mempengaruhi harga beras di Kota Bengkulu, tetapi tidak berlaku sebaliknya.

\section{Bengkulu Utara}

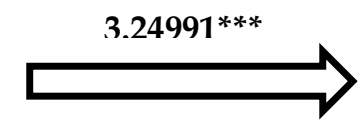

\section{Keterangan : $\longrightarrow$ Arah kausalitas}

Sumber : Hasil Analisis Data Sekunder (2014)

\section{Gambar 3.}

\section{Kausalitas antara Kota Bengkulu dengan Bengkulu Utara}

Dari gambar tersebut terlihat bahwa harga beras Bengkulu Utara mempengaruhi harga beras Kota Bengkulu, tetapi harga beras Kota Bengkulu tidak mempengaruhi harga Bengkulu Utara. Hal ini dikarenakan produksi beras Bengkulu Utara merupakan yang terbesar (lumbung beras utama) untuk Propinsi Bengkulu. Produksi padi Bengkulu Utara rata-rata per tahun dari tahun 2008- 2012 mencapai 80.000 ton, merupakan produksi tertinggi diseluruh kabupaten yang ada di Propinsi Bengkulu. Begitu juga dengan surplus beras yang dimilikinya hampir 16.000 ton/tahun, dan surplusnya ini cukup untuk cadangan 7 bulan.

\section{Kausalitas Bengkulu Utara dengan Rejang Lebong}

Berdasarkan nilai F-statisik di atas, terlihat bahwa pasar beras Bengkulu Utara dengan pasar beras Rejang Lebong memiliki hubungan satu arah (Fstatistik Bengkulu Utara- Rejang Lebong $=5.59944^{* * *}$ dan F-statistik Rejang Lebong - Bengkulu Utara $=0.54147 \mathrm{~ns})$. Hal ini menunjukkan bahwa harga beras 
Bengkulu Utara akan mempengaruhi harga beras di Rejang Lebong, tetapi tidak berlaku sebaliknya.
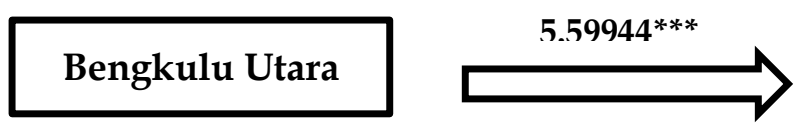

Rejang Lebong

\section{Keterangan : $\longrightarrow$ Arah kausalitas}

Sumber : Hasil Analisis Data Sekunder (2014)

\section{Gambar 4.}

\section{Kausalitas antara Bengkulu Utara dengan Rejang Lebong}

Dari gambar tersebut terlihat bahwa harga beras Bengkulu Utara mempengaruhi harga beras Rejang Lebong, tetapi harga beras Rejang Lebong tidak mempengaruhi harga Bengkulu Utara yang disebabkan olehtingginya produksi beras Bengkulu Utara. Sementara itu berdasarkan data tahun 2008 sampai 2012, surplus beras yang ada di Rejang Lebong hanya sekitar 9.838 ton/tahun atau surplus hanya cukup untuk 4 bulan. Produksi padi Bengkulu Utara rata-rata per tahun dari tahun 2008-2012 mencapai 80.000 ton, merupakan produksi tertinggi diseluruh kabupaten yang ada di Propinsi Bengkulu. Begitu juga dengan surplus beras yang dimilikinya hampir 16.000 ton/tahun, dan surplus ini cukup untuk cadangan 7 bulan.

\section{Kausalitas Bengkulu Selatan dengan Rejang Lebong}

Berdasarkan nilai F-statisik di atas, menunjukkan bahwa pasar beras Bengkulu Selatan memiliki hubungan satu arah dengan beras Rejang Lebong (F-statistik Bengkulu Selatan - Rejang Lebong $=7.57261^{* * *}$ ) dan F-statistik Rejang Lebong - Bengkulu Selatan $\left.=2.21262^{n s}\right)$. Hal ini menunjukkan bahwa harga beras Bengkulu Selatan akan mempengaruhi harga beras di Rejang Lebong, tetapi tidak berlaku sebaliknya.

Berdasarkan nilai F-statistik juga terlihat bahwa Bengkulu Selatan berpengaruh paling besar terhadap Rejang Lebong dibandingkan dengan pengaruh dari daerah lain yaitu Bengkulu Utara dan Kota Bengkulu (F-statistik Bengkulu Selatan 7.57261>Bengkulu Utara 5.59944>Kota Bengkulu 4.42261). Penyebab dari besarnya pengaruh harga beras Bengkulu Selatan terhadap Rejang Lebong melebihi pengaruh daerah lain ini disebabkan karena keunggulan komparatif dan kompetitif yang dimilikinya. Dengan pasar yang effisien mengindikasikan bahwa rantai pemasaran beras di Bengkulu Selatan tidak terlalu panjang dan tidak ada mata rantai yang mengambil marjin terlalu besar (abuse market power).

142 | Cahya Suryana, Putri Suci Asriani, dan Redy Badrudin, Perilaku Harga 


\section{Kausalitas Bengkulu Utara dengan Bengkulu Selatan}

Berdasarkan nilai F-statisik di atas, terlihat bahwa pasar beras Bengkulu Utara dengan pasar beras Bengkulu Selatan memiliki hubungan satu arah (Fstatistik Bengkulu Utara-Bengkulu Selatan $=4.93906^{* * *}$ dan F-statistik Bengkulu Selatan - Bengkulu Utara=2.34733ns). Hal ini menunjukkan bahwa harga beras di Bengkulu Utara akan mempengaruhi harga beras di Bengkulu Selatan, tetapi tidak berlaku sebaliknya.

\section{Pasar Referensi Penjualan Beras di Propinsi Bengkulu}

Leader Market adalah pasar yang lebih dominan dalam penentuan harga. Leader market atau pasar pemimpin ini dapat dijadikan referensi untuk tujuan penjualan. Berdasarkan hasil uji Granger Causality yang telah dibahas diatas, terlihat bahwa yang menjadi leader untuk pasar beras di antara Kota Bengkulu, Kabupaten Rejang Lebong, Kabupaten Bengkulu Utara dan Kabupaten Bengkulu Selatan adalah Kabupaten Bengkulu Utara. Pengaruh (causality) antara pasar beras di Kota Bengkulu, Rejang Lebong, Bengkulu Utara dan Bengkulu Selatan dapat dilihat pada gambar di bawah ini.

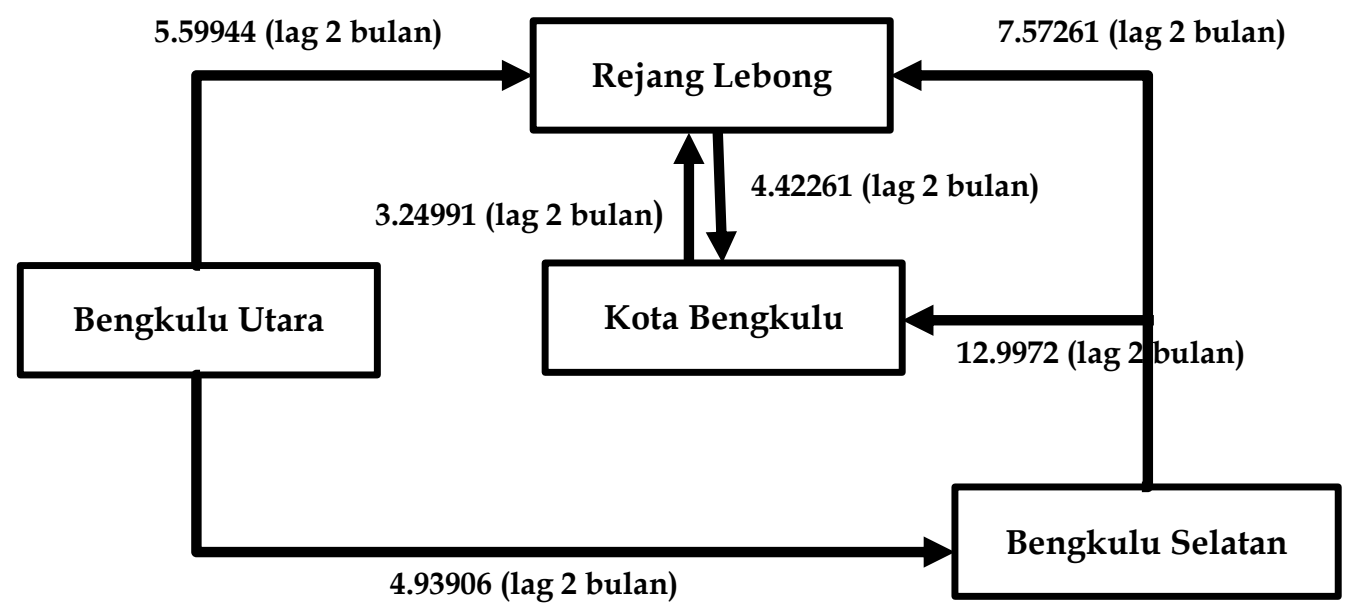

Keterangan : $\longrightarrow$ Arah kausalitas

Sumber : Hasil Analisis Data Sekunder (2014)

Gambar 6.

Diagram Kausalitas Harga Beras antar 4 Kabupaten/Kota di Propinsi Bengkulu.

Dari gambar diatas dapat dilihat tidak ada satupun kota/kabupaten yang mempengaruhi (mengarah) kepada Bengkulu Utara, sebaliknya terlihat dari 
Bengkulu Utara mempengaruhi (mengarah) ke semua kota/kabupaten lain. Hal ini menunjukan bahwa Bengkulu utara merupakan pemimpin (leader) dalam penentuan harga beras di Propinsi Bengkulu.

Beberapa alasan lain mengapa Bengkulu Utara menjadi leader adalah karena berhasilnya program Penguatan Lembaga Distribusi Pangan Masyarakat (P-LDPM) dibandingkan kabupaten lain. Seperti diketahui bahwa LDPM bertujuan untuk mewujudkan stabilisasi harga pangan ditingkat petani melalui:(a) Pengembangan unit- unit usaha (unit usaha distribusi atau pemasaran atau pengolahan dan pengelolaan cadangan pangan) dan (b) Pembangunan sarana penyimpanan milik Gapoktan agar meningkatkan posisi tawar petani, meningkatkan nilai tambah produk petani dan mendekatkan akses masyarakat terhadap sumber pangan.

Di Bengkulu Utara ada dua Gapoktan yaitu Gapoktan "Rawang Rumbai" dan Gapoktan “Bumay Jayo" yang berstatus Gapoktan Pasca Mandiri dan Gapoktan Pengembangan dalam program Penguatan Lembaga Distribusi Pangan Masyarakat (P-LDPM), dimana pada tahun 2012 pernah mendapat bantuan sebesar Rp 225 juta dan 150 juta. Faktor lain yang menyebabkan Bengkulu Utara menjadi leader dalam penentuan harga beras di Propinsi Bengkulu adalah banyaknya kelembagaan tani khususnya kelompok tani yang sudah maju/professional paling tidak menurut kriteria Badan Ketahanan Pangan Propinsi Bengkulu. Pada tahun 2013 ada 5 Kelompok Tani dari Bengkulu Utara sebagai Lumbung Pangan yang 4 diantaranya mendapat nilai "Baik" dan 1 mendapat nilai "Cukup Baik" , bandingkan dengan Rejang Lebong yang hanya memiliki 4 Ketompok Tani yang hanya 2 Kelompok Tani yang mendapat nilai "Baik" dan 2 lagi mendapat nilai "Cukup Baik". Sementara Bengkulu Selatan hanya memiliki 4 Kelompok Tani, dua mempunyai nilai "Baik" dan lainnya lagi memiliki nilai "Kurang Baik". Salah satu dasar dari penilain tersebut adalah kemampuan manajerial pengurus Kelompok Tani dan kemampuan pendistribusian dan pemasaran beras.

Hal yang sebaliknya terjadi pada Rejang Lebong, dimana tidak ada satupun kota yang dipengaruhinya memiliki jumlah surplus beras yang lebih rendah yakni memiliki surplus rata-rata per tahun hanya 9.300 ton (periode 2008-2012). Surplus beras yang dimiliki Rejang Lebong hanya cukup untuk 4 bulan, sementara surplus Bengkulu Utara mampu mencukupi sampai 7 bulan dan Bengkulu Selatan mencapai 15 bulan. Dalam konstelasi antara 4 kota/kabupaten yang dianalisa dalam penelitian ini, terlihat bahwa posisi Rejang Lebong bertindak sebagai konsumen akhir, bukan sebagi distributor apalagi sebagai produsen beras untuk Propinsi Bengkulu. Hal ini senada dengan hasil penelitian Irawan dan Rosmayanti (2007) tentang Integrasi Pasar Beras di Propinsi Bengkulu. Menurut penelitiannya terjadi integrasi spasial antar pasar tetapi belum terintegrasi secara penuh. 


\section{SIMPULAN DAN SARAN}

\section{Simpulan}

Berdasarkan hasil penelitian dan pengujian empiris di atas dapat disimpulkan bahwa:

1. Hasil analisis perilaku harga beras di Propinsi Bengkulu menunjukan hasil bahwa harga beras di Propinsi Bengkulu relatif stabil (tidak berfluktuasi). Hal ini ditunjukan oleh nilai koefisien variasi (KV) yang sangat kecil yaitu Kota Bengkulu (KV=0.521\%), Rejang Lebong ( $\mathrm{KV}=0.0496 \%)$, Bengkulu Utara $(\mathrm{KV}=0.0526 \%)$ dan Bengkulu Selatan (KV=0.0492\%). Meskipun demikian Kota Bengkulu lebih berfluktuasi (lebih tidak stabil) dibanding tiga daerah lainnya.

2. Dalam pemasaran beras di Propinsi Bengkulu terbukti terdapat integrasi (keterpaduan) pasar yang kuat dalam pembentukan harga antara harga beras Kota Bengkulu, Rejang Lebong, Bengkulu Utara dan Bengkulu Selatan.

3. Dari uji kausalitas terbukti bahwa harga beras Bengkulu Utara mempengaruhi harga beras Kota Bengkulu, Rejang Lebong dan Bengkulu Selatan, dan tidak ada satupun dari tiga daerah tersebut yang mempengaruhi harga beras Bengkulu Utara.

\section{Saran}

1. Mengingat pentingnya stabilitas harga beras yang sudah dicapai oleh PropinsiBengkulu maka untuk mempertahankanya pemerintah dapat menggalakan program Lembaga Distribusi Pangan Masyarakat (LDPM) untuk seluruh kabupaten yang ada di Propinsi Bengkulu.

2. Memperbaiki sarana dan prasarana pemasaran beras, termasuk penyebaran informasi dan akses masuk kepada leader market pasar beras Bengkulu.

CATATAN: Artikel ini merupakan bagian dari thesis dengan judul yang sama dari Cahya Suryana. 


\section{DAFTAR PUSTAKA}

Alimoeso, S. 2011. Kebijakan Pangan, BULOG dan Ketahanan Pangan. Makalah Lustrum XIII Fakultas Pertanian UGM. Yogyakarta.

Anindita, R. 2004. Pemasaran Hasil Pertanian. Papyrus. Surabaya.

Asriani, Putri S. 2013. Formulasi Diversifikasi Pangan Pokok Sumber Karbo Hidrat di Propinsi Bengkulu. Laporan Penelitian Fundamental. Universitas Bengkulu, November 2013.

BPS. 2013. Luas Panen, Produksi dan Produktivitas Padi menurut Kabupaten/Kota di Propinsi Bengkulu pada Tahun 2013. Berita Resmi Stasistik, Badan Pusat Statistik Propinsi Bengkulu. Bengkulu

Irawan, A dan Dewi Rosmayanti. 2007. Analisis Integrasi Pasar Beras di Bengkulu. Jurnal Agro Ekonomi; 25(1), Mei, 2007.

KPPU. 2007. Kajian Industri dan Perdagangan Sektor Industri Beras.

Lantarsih, R. 2012. Permintaan, Penawaran, Transmisi Vertikal Harga Beras dan Kebijakan Perberasan di Indonesia. Disertasi, UGM. Yogyakarta.

Nidausoleha, O. 2007. Analisis Perilaku Harga dan Keterpaduan Pasar Komoditas Bawang Merah di Jawa. Tesis Sekolah Pascasarjana UGM, Yogyakarta.

Prastowo, et. al. 2008. Pengaruh Distribusi dalam Pembentukan Harga Komoditas dan Implikasinya terhadap Inflasi. Working Paper BI Edisi WP/07/2008. Juni, 2008. www.bi.go.id

Sandra, P.S. Asriani, W. Rasyid. 2012. Analisis Perilaku Harga dan Keterpaduan Pasar Cabai Merah Keriting (Capsicum Annum) di Propinsi Bengkulu. Jurnal Agrisep; 11 (2) : 220-236, September 2012.

Widarjono, A. 2013. Ekonometrika : Pengantar dan Aplikasinya. Edisi 4. UPP. STIM. YKPN. Yogjakarta. 